\title{
Genetic diversity analysis in aromatic rice genotypes using microsatellite based simple sequence repeats (SSR) marker
}

\author{
Netravati Meti ${ }^{1}$, K. C. Samal ${ }^{1}$, D. N. Bastia ${ }^{2}$ and G. R. Rout ${ }^{1 *}$ \\ ${ }^{1}$ Department of Agricultural Biotechnology, College of Agriculture, Orissa University of Agriculture and Technology, \\ Bhubaneswar-751003, Odisha, India. \\ ${ }^{2}$ Department of Plant Breeding and Genetics, College of Agriculture, Orissa University of Agriculture and Technology, \\ Bhubaneswar-751003, Odisha, India.
}

Accepted 17 June, 2013

\begin{abstract}
The microsatellite or simple sequence repeat (SSR) markers were used to determine the allelic diversity and relationship among $\mathbf{4 8}$ traditional indigenous aromatic rice germplasm grown under Eastern part of India. Out of 30 primers, 12 primers showed DNA amplification and polymorphism among 48 aromatic rice genotypes. A total of 28 bands appeared by using 12 SSR primers in 48 aromatic rice varieties/landraces. The number of alleles per locus ranged from 1 to 5 with an average 2.08. Out of 28 bands, 25 bands were polymorphic and three were monomorphic bands. The results reveal that all the tested primers showed distinct polymorphism among the landraces/varieties indicating the robust nature of SSR markers. Most of the primers showed highest polymorphic information content (PIC). Phenotypic characteristics are significantly correlated with genotypic characters. The cluster analysis indicates that the 48 traditional indigenous aromatic rice genotypes were grouped into two major clusters. Among the two major clusters, one cluster had 11 varieties and the second cluster had 37 varieties on the basis of the group of land races. Based on this study, the larger range of similarity values using SSR markers provides greater confidence for the assessment of genetic relationships among the varieties. The information obtained from the SSR profile helps to identify the variety diagnostic markers in $\mathbf{4 8}$ traditional indigenous aromatic rice genotypes. Significant genetic variation at maximum number of loci between varieties indicates rich genetic resources in rice. The intra and inter genetically variation might be useful for breeders to improve the aromatic rice varieties through selective breeding and cross breeding programs and also protect these unique germplasm under Intellectual Property Rights (IPR).
\end{abstract}

Key words: Aromatic Rice, Oryza sativa, DNA profile, diagnostic polymerase chain reaction simple sequence repeat (PCR-SSR) marker, polymorphism, genetic diversity.

\section{INTRODUCTION}

Rice (Oryza sativa L.) $(2 \mathrm{n}=24)$ belonging to the family,

Poaceae and subfamily, Oryzoidea is the staple food for

*Corresponding author. E-mail: *Corresponding author. E-mail: grrout@rediffmail.com.

Abbreviations: CBT, Conservation of biological diversity; CTAB, N-cetyl-N, N, N-trimethyl ammonium bromide; PCA, principal component analysis; SSRs, simple sequence repeats; PCR, polymerase chain reaction; PIC, polymorphic information content. 
half of the world's population and occupies almost onefifth of the total land area covered under cereals. It is one of the very few crop species endowed with rich genetic diversity which account over 100,000 landraces and improved cultivars. Being the secondary centre of origin of cultivated rice, Odisha, India has the distinction of possessing about 10,000 to 15,000 traditional rice varieties out of 45,000 to 50,000 found in the world (Ray, 2007). Among these traditional rice varieties, land races of aromatic rice bear special significance because of their special flavour and economic value in the present globalized era (Chaudhury et al., 2001). The improvement of indigenous small and medium grained aromatic rice, which possesses outstanding quality like aroma, kernel elongation after cooking, fluffiness and taste were somewhat neglected as they lacked export value. Little attention has been paid to their improvement except for sporadic reports on germplasm evaluation and genetics of some quality trait. Scanty information is available on genetic diversity of traditional indigenous aromatic rice germplasm. Therefore, these varieties have to be collected and evaluated for their exploitable genetic variability and conserved. Further, management of the indigenous aromatic rice genetic resources by way of characterisation and documentation helps in protection of these unique bio-resources in accordance with the provision laid out in the 1992 to meet on conservation of biological diversity (CBT). Some of these genotypes are being gradually eroded from their respective places of origin and are on the verge of becoming extinct due to competition from high yielding varieties, difficulties of cultural practices and improper means of storage (Ram et al., 2007).

Among Asian rice growing countries, India is a major producer of many rice varieties such as aromatic rices and old landraces. In the context of global biodiversity loss, India missed several rice varieties/landraces. Therefore, it is highly necessary not only to conserve the landrace genotypes but also to investigate the gene-pool of aromatic rice for breeding purposes of high yielding varieties/landraces in the country. Characterization of varieties based on morphological characters is not very reliable because major characters have low heritability and are genetically complex warranting more precise techniques. For this purpose, identification of different genoypes at molecular level is imperative. The DNAbased markers are promising and effective tools for measuring genetic diversity in plants germplasm and elucidating their evolutionary relationships. They are more reliable, and remain unaffected across different growth stages, seasons, locations and agronomic practices. Amongst the polymerase chain reaction (PCR) based markers, the microsatellites [also known as simple sequence repeats (SSRs)] are useful as genetic markers because they detect high levels of allelic diversity. These are co-dominant, easily and distributed throughout the genome. More than 20,000 microsatellite markers have been mapped to specific locations in rice genome (www.irgsp.org) (Pervaiz et al., 2009). The advent of genomic sequences in rice offers new opportunities to enhance the density of locus specific and polymorphic markers for high-resolution genetic analysis. Owing to technical efficiency and multiplex potential,

these markers are preferable for many forms of high throughput mapping, genetic analysis and marker assisted plant improvement strategies (Nagaraju et al., 2002). Molecular markers have been extensively used to identify genetic variation among rice germplasm (Nagaraju et al., 2002; Yu et al., 2003; Ren et al., 2003; Jain et al., 2004; Zeng et al., 2004; Garris et al., 2005; Shishido et al., 2006; Gao et al., 2005; Jayamani et al., 2007; Sajib et al., 2012). In the present study, a set of 12 microsatellite markers distributed on 12 different chromosomes of rice genome were used for DNA profiling of 48 indigenous aromatic rice genotypes to characterize and detect genetic diversity within these cultivars at molecular level.

\section{MATERIALS AND METHODS}

The aromatic rice varieties were collected from the Eastern parts of the India and were maintained in the Rice Research station, Orissa, University of Agriculture and Technology (OUAT), Bhubaneswar, India. 48 elite aromatic rice varieties were selected for phenotypic and molecular analysis (Table 1). The genotypes were grown in Randomized Complete Block Design with three replications during kharif season for three consecutive years. The plot size for each variety was $3.0 \times 3 \mathrm{~m}$ and a spacing of $20 \mathrm{~cm}$ between lines and 10 $\mathrm{cm}$ between plants were provided. The standard recommended agronomic practices were followed for raising the crop. Observation on different quantitative characters viz. plant height, days to flowering, panicle length, panicle number, number of fertile grains, 1000 grain weight, yield and other phenotypic characters were recorded. The observations of different quantitative characters were recorded as per DUS (distinctness, uniformity, stability) guidelines.

\section{Isolation of rice genomic DNA}

Leaf samples were collected and subsequently stored at $-20^{\circ} \mathrm{C}$ for isolation of genomic DNA. The genomic DNA was extracted from young leaves using $\mathrm{N}$-Cetyl-N, N, N-trimethyl ammonium bromide (CTAB) method described by Doyle and Doyle (1990) with slight modifications. $2 \mathrm{~g}$ of fresh leaf material were washed in distilled water and subsequently rinsed with $80 \%(\mathrm{v} / \mathrm{v})$ ethanol and then ground in liquid nitrogen. $10 \mathrm{ml}$ of preheated extraction buffer [4\% $(w / v)$ CTAB, 0.2\% $\beta$-mercaptoethanol (v/v), $100 \mathrm{mM}$ Tris- $\mathrm{HCl} \mathrm{pH}$ 8.0, $20 \mathrm{mM}$ EDTA pH 8.0, 1.4 M NaCl] were then added per $2 \mathrm{~g}$ of leaf powder material and incubated for $2 \mathrm{~h}$ at $65^{\circ} \mathrm{C}$. The lysate was purified with chloroform: isoamylalcohol (24:1). The DNA pellet was resuspended in 200 to $300 \mu \mathrm{l}$ of Tris-EDTA buffer (10 mM Tris $\mathrm{HCl}, 1 \mathrm{mM}$ EDTA, $\mathrm{pH}=8.0)$. DNA was reprecipitated by adding $80 \%$ ethanol in the presence of $0.3 \mathrm{M}$ sodium acetate, and pelleted by centrifugation. The pellets were lyophilized and resuspended in TE buffer. The RNA was removed by RNAse treatment at $37^{\circ} \mathrm{C}$ for $1 \mathrm{~h}$. For further purification, DNA solution was extracted once with equal volume of phenol and chloroform: isoamyl alcohol (24:1:1) followed by two extractions with chloroform: isoamylalcohol (24:1). The upper aqueous phase was separated after centrifugation and 
Table 1. Aromatic rice varieties and their distribution.

\begin{tabular}{|c|c|c|}
\hline $\mathbf{S} / \mathbf{N}$ & Genotype & Area of distribution \\
\hline 1 & Baranamgomati & Cuttack, Odisha \\
\hline 2 & Basnasapuri & Puri, Odisha \\
\hline 3 & Basnaparijat & Puri, Odisha \\
\hline 4 & Basumati-1 & Puri, Odisha \\
\hline 5 & Basmatidhan & Keonjhar, Odisha \\
\hline 6 & Basumati Bhog & Koraput, Odisha \\
\hline 7 & Chatianaki & Cuttack, Odisha \\
\hline 8 & Dhobaluchi & Phulbani, Odisha \\
\hline 9 & Krishnabhoga & Bolangir, Odisha \\
\hline 10 & Manasi-2 & Puri, Odisha \\
\hline 11 & Nuakalajeera & Puri, Odisha \\
\hline 12 & Nuadhusura & Cuttack, Odisha \\
\hline 13 & Pimpudibasa & Keonjhar, Odisha \\
\hline 14 & Ratnasundari & Kalahandi, Odisha \\
\hline 15 & Sujata & Puri, Odisha \\
\hline 16 & Srimula & Cuttack, Odisha \\
\hline 17 & Thakurbhog & Puri, Odisha \\
\hline 18 & Tulasiphada & Puri, Odisha \\
\hline 19 & Sheetabhog & Cuttack, Odisha \\
\hline 20 & Gopalabhoga & Puri, Odisha \\
\hline 21 & Tulasiphulla & Puri, Odisha \\
\hline 22 & Bhasumati (P) & Phulbani, Odisha \\
\hline 23 & Saragadhulli & Puri, Odisha \\
\hline 24 & Mugajai & Bolangir, Odisha \\
\hline 25 & Dholabankoi & Cuttack, Odisha \\
\hline 26 & Dubraj & Keonjhar, Odisha \\
\hline 27 & Dulhabhoga & Keonjhar, Odisha \\
\hline 28 & Dangarabasamati & Phulbani, Odisha \\
\hline 29 & Gangaballi & Phulbani, Odisha \\
\hline 30 & Ganjam local-1 & Ganjam, Odisha \\
\hline 31 & Ganjam local-2 & Ganjam, Odisha \\
\hline 32 & Ganjeikalli & Cuttack, Odisha \\
\hline 33 & Gatia & Puri, Odisha \\
\hline 34 & Heerakani & Dhenkanal, Odisha \\
\hline 35 & Jalaka-1 & Keonjhar, Odisha \\
\hline 36 & Jalaka-2 & Keonjhar, Odisha \\
\hline 37 & Jaiphulla & Keonjhar, Odisha \\
\hline 38 & Kalajeera & Puri, Odisha \\
\hline 39 & Kalajauvan & Puri, Odisha \\
\hline 40 & Khosakani & Koraput, Odisha \\
\hline 41 & Kaminibhoga-1 & Bolangir, Odisha \\
\hline 42 & Kaminibhoga-2 & Bolangir, Odisha \\
\hline 43 & Kalikati-2 & Kalahandi, Odisha \\
\hline 44 & Kalikati-1 & Kalahandi, Odisha \\
\hline 45 & Kanakachampa & Keonjhar, Odisha \\
\hline 46 & Kusumabhoga & Denkanal, Odisha \\
\hline 47 & Karpurakranti & Bolangir, Odisha \\
\hline 48 & Manasi-1 & Puri, Odisha \\
\hline
\end{tabular}

mixed with $1 / 10$ th volume of $3 \mathrm{M}$ sodium acetate. DNA was precipitated by adding two volumes of chilled absolute alcohol, pelleted, dried in vacuum and dissolved in TE buffer. Quantification of DNA was accomplished by analyzing the purified DNA on $0.8 \%$ $(w / v)$ agarose gel electrophoresis along side diluted uncut lambda DNA as standard. DNA was further diluted with TE to a concentration of $20 \mathrm{ng} / \mu \mathrm{l}$ for use in PCR analysis.

\section{PCR amplification and electrophoresis}

A set of 12 mapped microsatellite markers distributed on all the 12 chromosomes (McCouch et al., 1997; Temnykh et al., 2000) were used for the analysis of 48 aromatic rice genotypes. The number of markers per chromosome was one. These microsatellite primers were purchased from commercially available microsatellite primer kits (Merck Bioscience, USA). Individual PCR amplifications for each microsatellite were performed in programmable thermal controller (BioRad, California, USA). The PCR protocol involved a total volume of $25 \mu \mathrm{l}$ reaction mixture (Sambrook et al., 1989) containing $35 \mathrm{ng}$ of genomic DNA, 1X PCR buffer (pH 8.3), $200 \mu \mathrm{M}$ dNTP mix, 10 pmol of each of the forward and reverse primers, 2 $\mathrm{mM}$ of $\mathrm{MgCl}_{2}$ and $1 \mathrm{U}$ of Taq (Thermophilus aquaticus) DNA polymerase (Merck Bioscience). The basic PCR program to amplify DNA was as follows: an initial hot start and denaturing step at $93^{\circ} \mathrm{C}$ for 3 min followed by 40 cycles of a 1 min denaturation at $93^{\circ} \mathrm{C}$, a 1 min annealing at appropriate temperature $\left(52\right.$ or $\left.67^{\circ} \mathrm{C}\right)$ depending on the primer), and a $1 \mathrm{~min}$ primer elongation at $72^{\circ} \mathrm{C}$. A final extension step at $72^{\circ} \mathrm{C}$ for 5 min was performed.

\section{Gel electrophoresis}

A $10 \mu \mathrm{l}$ aliquot of the amplified microsatellite samples was combined with $2 \mu \mathrm{l}$ of a loading buffer $(0.4 \%$ bromophenol blue, $0.4 \%$ xylene cyanole and $5 \mathrm{ml}$ of glycerol) and was loaded directly on $2.5 \%$ agarose gels in 0.5X TBE buffer (Sambrook et al, 1989). Electrophoresis was done for about $3 \mathrm{~h}$ at $60 \mathrm{~V}$. Low range DNA ruler (Merck Bioscience) was used to compare the molecular weights of amplified products. Visualization of the amplified bands was done by staining with ethidium bromide for $20 \mathrm{~min}$ and destaining with double distilled water for $20 \mathrm{~min}$ followed by transillumination under short wave UV light (Gel Doc. 2000, BioRad, California, USA).

\section{Data analysis}

Polymorphic products from microsatellite analyses were scored qualitatively for presence (1) and absence (0) for each marker allele-genotype combination. The data entry was done into a binary data matrix as discrete variables. Most informative primers were selected based on the extent of polymorphism. The polymorphic information content (PIC) was calculated by applying the formula given by Powell et al. (1996):

$$
\mathrm{PIC}=1-\sum_{\mathrm{i}=1}^{\mathrm{n}} f^{2}
$$

Where, $f_{i j}$ is the frequency of $j^{\text {th }}$ allele for marker $i$ and the summation extends over $n$ alleles. PIC values range from 0 (monomorphic) to 1 (very highly discriminative, with many alleles each in equal and low frequency). Pair-wise similarity matrices based on DNA profile data were determined using Jaccard's similarity coefficient (JSC) (Sneath and Sokal, 1973). Genetic relationships among the genotypes studied were calculated using UPGMA cluster analysis and Principal Component Analysis (PCA) of the similarity matrix obtained from the proportion of shared amplification fragments. All those analyses were computed with the program NTSYSpc 2.2 (Exeter Software, Stauket, NY, USA) (Rohlf, 2002).

\section{RESULTS AND DISCUSSION}

Morphological and seed traits have the important means 
of studying the taxonomy and variability among plant species. Traditional rice varieties, or landraces, have a high level of genetic heterogeneity compared to modern varieties. This genetic variability is utmost important for the sustainability of small marginal farmers, because despite the low yield capacity, these varieties /landraces present high tolerant to abiotic and biotic stresses. The phenotypic characteristics, seed morphology and their distribution of 48 traditional indigenous aromatic rice germplasm are presented in Table 2 and Figure 1. Landraces are adapted to local, small-scale, low-input environments where the plant ideotype may differ considerably from that developed for modern agricultural systems (Veteläinen et al., 1997). The evaluation of the genetic variability of accessions of landraces can provide the basic information necessary to help properly conserve these genetic resources. This will also help breeding programs to plan crosses to incorporate this variability into the genetic background of elite rice germplasms, which in turn will generate new rice cultivars. The microsatellites or SSRs are amongst the most widely used DNA marker for various purposes such as diversity, genome mapping and varietal identification (Nagaraju et al., 2002; Singh et al., 2004). The present study aimed to determine the genetic diversity of 48 traditional indigenous aromatic rice germplasm of Indian origin by using 12 SSR markers (Table 3 ). The results indicated a high level of genetic variation in the germplasm tested. A total of 28 different reproducible bands (alleles) ranging in size from $100 \mathrm{bp}$ to $220 \mathrm{bp}$ were amplified (Figure 2 and Table 4). The average number of bands per primer was found to be 2.33. Of the total 28 bands generated, 25 SSR bands were polymorphic whereas 1 bands generated from the SSR primer RM-44 and 2 bands in RM-154 were monomorphic. The average number of polymorphic bands per primer was 2.08. The PIC ranged from 0 to 0.74 with an average of 0.582 . Pairwise estimates of similarity matrix ranged from 0.20 to 0.92 and average Jaccard's similarity among all 48 genotypes was 0.5 . The cluster analysis by using UPGMA algorithm indicated that all the 48 aromatic rice germplasm were grouped into two Clusters (I and II) at $49 \%$ similarity coefficient (Figure 3 ). 11 aromatic rice genotypes were represented in Cluster I whereas 37 varieties were placed in Cluster II. Cluster I was divided into two sub-clusters ' $I A$ ' and 'IB' at $56 \%$ similarity coefficient. The sub-cluster 'IA' included seven aromatic rice varieties in which 'Kaminibhog-1' and 'Kalikati-1' were most similar genotypes within sub-cluster. The genotypes included in this sub-cluster were 'Bananangemati', 'Gatia', 'Kaminibhog-1', 'Kalikati-1', 'Dhobalachi', 'Ganjeikalli' and 'Jiphulla'. On the other hand the sub-cluster 'IB' was represented by the following four aromatic rice varieties 'Bhasumatidhan' 'Basumati Bhog', 'Chatianak' and 'Pumpudibasa'. Among them 'Basumati dhan' was the most diverged one in this sub-cluster. The cluster II was further classified into two sub-clusters 'IIA' and 'IIB'. There were 35 aromatic rice varieties included in the sub-cluster 'IIA' whereas only two aromatic rice varieties 'Dubraj' and 'Sujata' were placed in Cluster 'IIB'. Further at $68 \%$ similarity coefficient, the sub-cluster 'IIA' was divided into 3 subsub-clusters. Sub-sub-Cluster 'IIA $A_{1}$ ' was represented by 7 aromatic rice germplasm among them 'Basnaparijat' was the most diverse one. In this sub-sub-cluster, the rice varieties 'Kalikati-2' and 'Karpurkranti' had shown the maximum similarity (100\%). Similarly, ten aromatic rice germplasm placed in sub-sub-cluster ' $I I \mathrm{~A}_{2}$ ' and among them 'Sirimula' and 'Tulashiphula' exhibited the maximum similarity $(100 \%)$. In Sub-sub-cluster ' $I I A_{3}$ ', the highest number of aromatic rice varieties (18) were placed. The aromatic rice variety 'Khoshkani' and 'Kaminibhog-2' had the maximum similarity (100\%). Another pair of genotypes (Ratnasundari' and 'Tulasiphada) had also exhibitted maximum similarity.

All the genotypes re-presented in this sub-cluster were similar with respect to most of the morphological characters. The PIC ranged from 0 to 0.74 with an average of 0.582 . Thomson et al. (2007) analyzed 246 Indonesian accessions and 63 Indonesian improved cultivars, using 30 fluorescently-labeled micro-satellite markers and reported that a total of 394 alleles were detected at the 30 simple sequence repeat loci, with an average number of 13 alleles per locus across all accessions, and an average polymer-phism information content value of 0.66 . Further, Jain et al. (2004) used 30 fluorescently labeled rice microsatellite markers and achieved a total of 235 alleles detected at the 30 SSR loci, $62(26.4 \%)$ of which were present only in Basmati and other scented rice germplasm accessions. The number of alleles per locus ranged from 3 to 22, with an average of 7.8 , PIC values ranged from 0.2 to 0.9 , with an average of 0.6 , and the size ranged between the smallest and the largest allele for a given microsatellite locus which varied between 3 and 68 bp. 19 SSR loci and 12 inter-SSR-PCR primers were used to assess the genetic relationships in traditional and evolved Basmati (EB) and semi dwarf non-Basmati (NB) rice varieties. A total of 70 SSR alleles and 481 inter-SSR-PCR markers were revealed in 24 varieties from the three groups (Aggarwal et al., 2002). Saini et al. (2004) evaluated the traditional Basmati, cross-bred Basmati and non-Basmati (indica and japonica) rice varieties using three DNA markers. All the three marker systems generated higher levels of polymorphism and could distinguish between all the 18 rice cultivars.

PCA analysis showed that the similarity values for related germplasm using SSRs provides greater confidence for the assessment of genetic diversity and relationships. The three-dimensional scaling of PCA analysis placed all the 48 traditional indigenous aromatic rice genotypes into four groups. Of the total 48 aromatic rice varieties, the first group contained 'Baranamgomati, 'Dhobaluchi', 'Pimpudibasa', 'Gatia', 'Jaiphulla', 'Kalikati- 
Table 2. Phenotypic diversity among 48 indigenous aromatic rice genotypes.

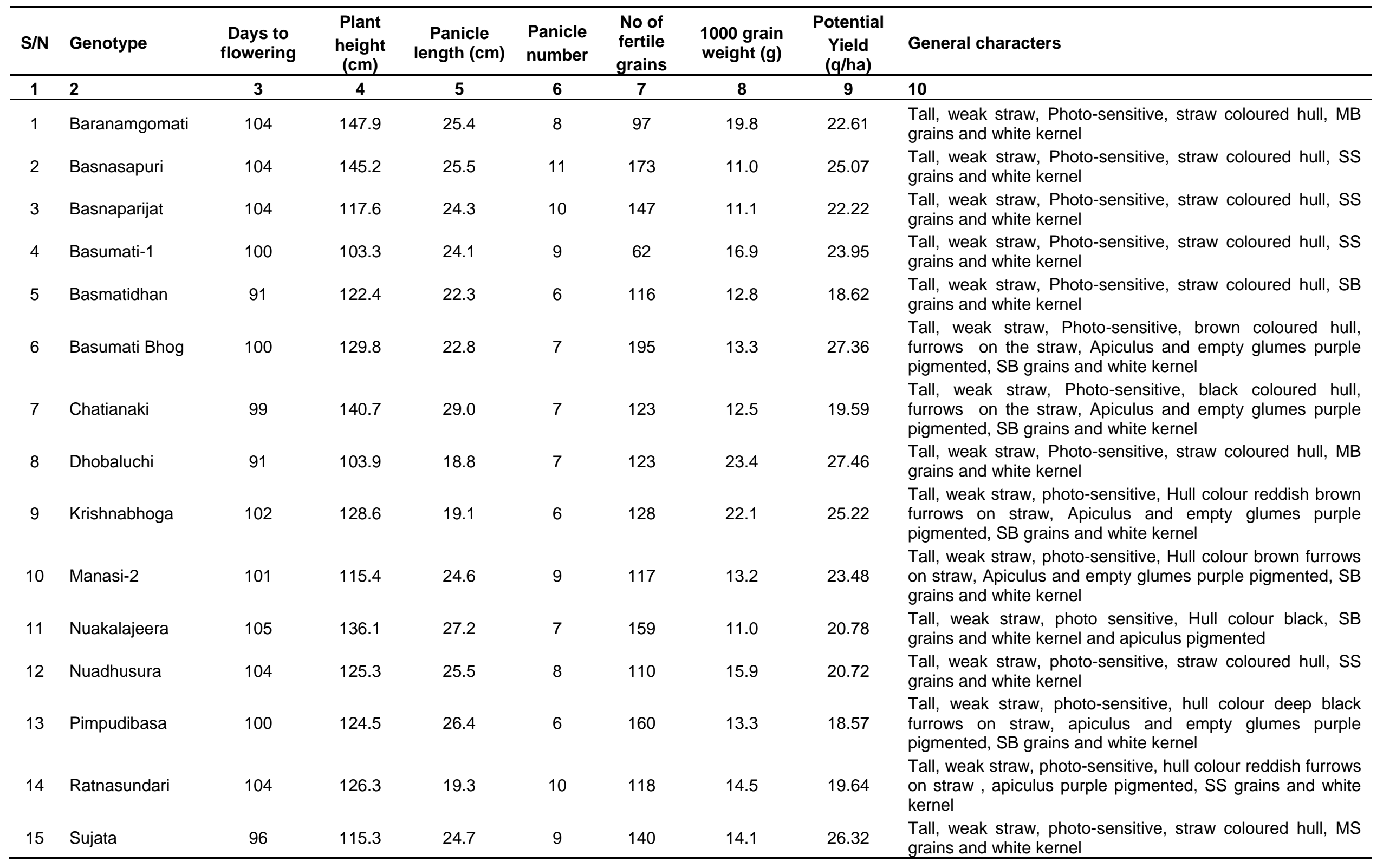

MB, Medium bold; SB- slender bold. 
Table 2. Contd.

\begin{tabular}{|c|c|c|c|c|c|c|c|c|c|}
\hline $\mathbf{S} / \mathbf{N}$ & Genotypes & $\begin{array}{l}\text { Days to } \\
\text { flowering }\end{array}$ & $\begin{array}{l}\text { Plant } \\
\text { Height } \\
\text { (cm) }\end{array}$ & $\begin{array}{l}\text { Panicle } \\
\text { length }(\mathrm{cm})\end{array}$ & $\begin{array}{l}\text { Panicle } \\
\text { number }\end{array}$ & $\begin{array}{l}\text { Nmber of } \\
\text { fertile } \\
\text { grains }\end{array}$ & $\begin{array}{l}1000 \text { grain } \\
\text { weight }(g)\end{array}$ & $\begin{array}{l}\text { Potential } \\
\text { Yield } \\
\text { (q/ha) }\end{array}$ & General characters \\
\hline 1 & 2 & 3 & 4 & 5 & 6 & 7 & 8 & 9 & 10 \\
\hline 16 & Srimula & 105 & 125.9 & 25.2 & 8 & 131 & 11.1 & 21.59 & $\begin{array}{l}\text { Tall, weak straw, photo-sensitive, straw coloured hull, SS } \\
\text { grains and white kernel }\end{array}$ \\
\hline 17 & Thakurbhog & 106 & 127.4 & 28.8 & 10 & 145 & 12.9 & 28.12 & $\begin{array}{l}\text { Tall, weak straw, photo-sensitive, hull colour black, apiculus } \\
\text { purple pigmented, SB grains and white kernel }\end{array}$ \\
\hline 18 & Tulasiphada & 102 & 123.4 & 27.3 & 6 & 126 & 13.8 & 24.70 & $\begin{array}{l}\text { Tall, weak straw, photo-sensitive, straw coloured hull, SS } \\
\text { grains and white kernel }\end{array}$ \\
\hline 19 & Sheetabhog & 103 & 120.6 & 23.6 & 8 & 145 & 10.7 & 19.13 & $\begin{array}{l}\text { Tall, weak straw, photo-sensitive, straw coloured hull, SS } \\
\text { grains and white kernel }\end{array}$ \\
\hline 20 & Gopalabhoga & 102 & 121.5 & 24.6 & 7 & 125 & 11.5 & 18.57 & $\begin{array}{l}\text { Tall, weak straw, photo-sensitive, straw coloured hull, SS } \\
\text { grains and white kernel }\end{array}$ \\
\hline 21 & Tulasiphulla & 98 & 110.8 & 23.2 & 9 & 108 & 13.7 & 10.49 & $\begin{array}{l}\text { Tall, weak straw, photo-sensitive, hull colour reddish brown } \\
\text { on straw, apiculus pigmented, SB grains and white kernel }\end{array}$ \\
\hline 22 & Bhasumati (P) & 97 & 126.3 & 24.4 & 8 & 125 & 12.4 & 23.54 & $\begin{array}{l}\text { Tall, weak straw, Photo-sensitive, straw coloured hull, SS } \\
\text { grains and white kernel }\end{array}$ \\
\hline 23 & Saragadhulli & 103 & 129.5 & 25.6 & 10 & 132 & 11.8 & 19.23 & $\begin{array}{l}\text { Tall, weak straw, photo-sensitive, hull colour reddish brown } \\
\text { furrows on straw , apiculus and empty glumes purple } \\
\text { pigmented, SB grains and white kernel }\end{array}$ \\
\hline 24 & Mugajai & 105 & 126.4 & 26.4 & 6 & 153 & 17.5 & 22.45 & $\begin{array}{l}\text { Tall, weak straw, photo-sensitive, straw coloured hull, } \\
\text { Apiculus purple pigmented, SB grains and white kernel }\end{array}$ \\
\hline 25 & Dholabankoi & 102 & 127.1 & 27.1 & 9 & 169 & 12.4 & 29.42 & $\begin{array}{l}\text { Tall, weak straw, Photo-sensitive, brown coloured hull, } \\
\text { furrows on the straw, Apiculus and empty glumes purple } \\
\text { pigmented, SB grains and white kernels }\end{array}$ \\
\hline 26 & Dubraj & 103 & 125.4 & 28.4 & 8 & 152 & 14.5 & 26.37 & $\begin{array}{l}\text { Tall, weak straw, Photo-sensitive, straw coloured hull, MS } \\
\text { grains and white kernel and awned }\end{array}$ \\
\hline 27 & Dulhabhoga & 100 & 125.2 & 23.0 & 7 & 141 & 18.9 & 17.65 & $\begin{array}{l}\text { Tall, weak straw, Photo-sensitive, brown coloured hull, } \\
\text { furrows on the straw, Apiculus and empty glumes purple } \\
\text { pigmented, SB grains and white kernels }\end{array}$ \\
\hline 28 & Dangarabasamati & 101 & 126.0 & 22.8 & 7 & 135 & 15.6 & 19.20 & $\begin{array}{l}\text { Tall, weak straw, Photo-sensitive, straw coloured hull, SS } \\
\text { grains and white kernel }\end{array}$ \\
\hline 29 & Gangaballi & 97 & 125.4 & 25.0 & 9 & 139 & 11.6 & 24.48 & $\begin{array}{l}\text { Tall, weak straw, Photo-sensitive, straw coloured hull, SS } \\
\text { grains and white kernel }\end{array}$ \\
\hline 30 & Ganjam local-1 & 98 & 123.0 & 23.9 & 8 & 137 & 11.8 & 19.20 & $\begin{array}{l}\text { Tall, weak straw, photo-sensitive, straw coloured hull, SS } \\
\text { grains and white kernel }\end{array}$ \\
\hline
\end{tabular}


Table 2. Contd.

\begin{tabular}{|c|c|c|c|c|c|c|c|c|c|}
\hline $\mathbf{S} / \mathbf{N}$ & Genotypes & $\begin{array}{l}\text { Days to } \\
\text { flowering }\end{array}$ & $\begin{array}{l}\text { Plant } \\
\text { Height } \\
(\mathrm{cm})\end{array}$ & $\begin{array}{l}\text { Panicle } \\
\text { length } \\
\text { (cm) }\end{array}$ & $\begin{array}{l}\text { Panicle } \\
\text { number }\end{array}$ & $\begin{array}{l}\text { Number of } \\
\text { fertile } \\
\text { grains }\end{array}$ & $\begin{array}{l}1000 \text { grain } \\
\text { weight }(g)\end{array}$ & $\begin{array}{l}\text { Potential } \\
\text { Yield } \\
\text { (q/ha) }\end{array}$ & General characters \\
\hline 1 & 2 & 3 & 4 & 5 & 6 & 7 & 8 & 9 & 10 \\
\hline 32 & Ganjeikalli & 95 & 127.1 & 19.4 & 10 & 130 & 18.3 & 25.42 & $\begin{array}{l}\text { intermediate height, stiff straw, Photo-sensitive, straw, } \\
\text { golden coloured hull, SB grains and dull white kernel }\end{array}$ \\
\hline 33 & Gatia & 107 & 136.2 & 23.2 & 8 & 135 & 18.0 & 24.37 & $\begin{array}{l}\text { Tall, weak straw, Photo-sensitive, straw, golden coloured } \\
\text { hull, apiculus pigmented, SB grains and dull white kernel }\end{array}$ \\
\hline 34 & Heerakani & 98 & 117.6 & 25.2 & 10 & 175 & 11.0 & 23.16 & $\begin{array}{l}\text { Tall, weak straw, photo-sensitive, straw coloured hull, SS } \\
\text { grains and white kernel }\end{array}$ \\
\hline 35 & Jalaka-1 & 104 & 107.4 & 24.7 & 6 & 112 & 14.2 & 22.81 & $\begin{array}{l}\text { Tall, weak straw, photo-sensitive, straw coloured hull, SS } \\
\text { grains and white kernel }\end{array}$ \\
\hline 36 & Jalaka-2 & 103 & 115.4 & 24.5 & 10 & 136 & 11.6 & 18.71 & $\begin{array}{l}\text { Tall, weak straw, photo-sensitive, straw coloured hull, SS } \\
\text { grains and white kernel }\end{array}$ \\
\hline 37 & Jaiphulla & 102 & 105.0 & 20.6 & 6 & 107 & 19.2 & 25.68 & $\begin{array}{l}\text { Tall, weak straw, photo-sensitive, straw coloured hull, MS } \\
\text { grains and white kernel }\end{array}$ \\
\hline 39 & Kalajauvan & 101 & 140.3 & 29.8 & 4 & 143 & 13.5 & 18.60 & $\begin{array}{l}\text { Tall, weak straw, photo-sensitive, Hull coloured brown } \\
\text { furrows on straw, SB grains and white kernel }\end{array}$ \\
\hline 40 & Khosakani & 104 & 127.8 & 27.4 & 7 & 174 & 13.9 & 28.41 & $\begin{array}{l}\text { Tall, weak straw, photo-sensitive, Black coloured hull, SB } \\
\text { grains, white kernel and apiculus pigmented }\end{array}$ \\
\hline 41 & Kaminibhoga-1 & 96 & 126.4 & 20.3 & 6 & 163 & 14.6 & 20.31 & $\begin{array}{l}\text { Tall, weak straw, photo-sensitive, Straw coloured hull, SS } \\
\text { grains and whit kernel }\end{array}$ \\
\hline 42 & Kaminibhoga-2 & 103 & 129.0 & 25.2 & 7 & 145 & 11.9 & 19.77 & $\begin{array}{l}\text { Tall, weak straw, photo-sensitive, Straw coloured hull, SS } \\
\text { grains and whit kernel }\end{array}$ \\
\hline 43 & Kalikati-2 & 105 & 141.1 & 27.7 & 13 & 174 & 12.3 & 24.07 & $\begin{array}{l}\text { Tall, weak straw, photo-sensitive, Red colour hull, SS } \\
\text { grains and white kernel }\end{array}$ \\
\hline 44 & Kalikati-1 & 101 & 133.1 & 24.9 & 7 & 164 & 10.9 & 21.39 & $\begin{array}{l}\text { Tall, weak straw, photo-sensitive, Hull colour reddish } \\
\text { brown furrows on straw, Apiculus and empty glumes } \\
\text { purple pigmented, SB grains and white kernel }\end{array}$ \\
\hline 45 & Kanakachampa & 98 & 135.6 & 24.5 & 7 & 146 & 12.1 & 18.62 & $\begin{array}{l}\text { Tall, weak straw, photo-sensitive, Straw coloured hull, } \\
\text { SS grains and white kernel }\end{array}$ \\
\hline 46 & Kusumabhoga & 97 & 128.2 & 22.1 & 12 & 138 & 13.6 & 19.42 & $\begin{array}{l}\text { Tall, weak straw, photo-sensitive, Hull colour brown } \\
\text { furrows on straw, Apiculous and empty glumes purple } \\
\text { pigmented, SB grains and white kernel }\end{array}$ \\
\hline 47 & Karpurakranti & 102 & 130.9 & 24.5 & 7 & 88 & 13.6 & 17.65 & $\begin{array}{l}\text { Tall, weak straw, photo-sensitive, Hull colour black } \\
\text { furrows on straw, Apiculus and empty glumes purple } \\
\text { pigmented, SB grains and white kernel }\end{array}$ \\
\hline
\end{tabular}


Table 2. Contd.

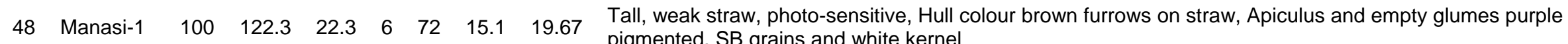
pigmented, SB grains and white kernel

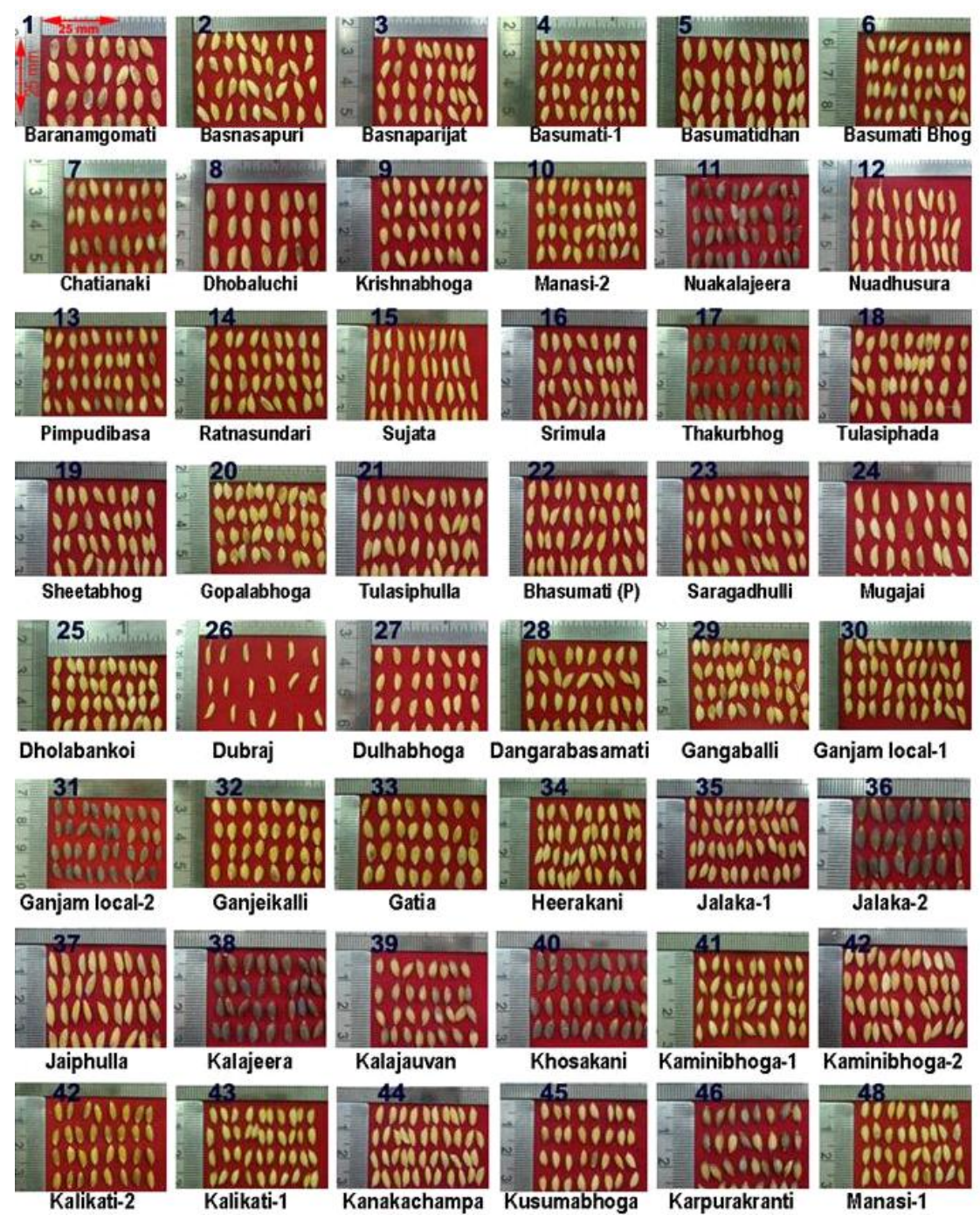

Figure 1. Grain morphology of 48 indigenous aromatic rice genotypes. 
Table 3. Details of the SSR primers used for genetic analysis.

\begin{tabular}{|c|c|c|c|c|}
\hline Primer & Sequence (5'-3') & $\mathrm{Tm}^{*}$ & $\mathrm{Ta}^{\star}$ & $\begin{array}{c}\text { Chromosome number of } \\
\text { rice genome }\end{array}$ \\
\hline \multirow[t]{2}{*}{ RM9 } & F-5 “ GGTGCCATTGTCGTCCTC 3" & $64.4^{\circ} \mathrm{C}$ & $62^{\circ} \mathrm{C}$ & 1 \\
\hline & R-5 “ACGGCCCTCATCACCTTC 3" & $65.2^{\circ} \mathrm{C}$ & $62^{\circ} \mathrm{C}$ & 1 \\
\hline \multirow[t]{2}{*}{ RM154 } & F-5 "ACCCTCTCCGCCTCGCCTCCTC 3" & $64.4^{\circ} \mathrm{C}$ & $62^{\circ} \mathrm{C}$ & 1 \\
\hline & R-5 "СTCСTCCTCCTGCGACCGCTCC 3" & $65.2^{\circ} \mathrm{C}$ & $62^{\circ} \mathrm{C}$ & 1 \\
\hline \multirow[t]{2}{*}{ RM218 } & F-5 “TGGTCAAACCAAGGTCCTTC 3” & $63.8^{\circ} \mathrm{C}$ & $55^{\circ} \mathrm{C}$ & 3 \\
\hline & R-5 “GACATACATTCTACCCCCGG 3" & $62.9^{\circ} \mathrm{C}$ & $55^{\circ} \mathrm{C}$ & 3 \\
\hline \multirow[t]{2}{*}{ RM241 } & F-5 "GAGCCAAATAAGATCGCTGA 3" & $61.8^{\circ} \mathrm{C}$ & $52^{\circ} \mathrm{C}$ & 4 \\
\hline & R-5 “TGCAAGCAGCAGATTTAGTG 3” & $61.7^{\circ} \mathrm{C}$ & $52^{\circ} \mathrm{C}$ & 4 \\
\hline \multirow{2}{*}{ RM249 } & F-5 “GGCGTAAAGGTTTTGCATGT 3” & $63.6^{\circ} \mathrm{C}$ & $52^{\circ} \mathrm{C}$ & 5 \\
\hline & R-5 “ATGATGCCATGAAGGTCAGC 3" & $65.0^{\circ} \mathrm{C}$ & $52^{\circ} \mathrm{C}$ & 5 \\
\hline \multirow[t]{2}{*}{ RM30 } & F-5 “GGTTAGGCATCGTCACGG 3” & $64.2^{\circ} \mathrm{C}$ & $55^{\circ} \mathrm{C}$ & 6 \\
\hline & R-5 “TCACCTCACCACACGACACG 3" & $68.7^{\circ} \mathrm{C}$ & $55^{\circ} \mathrm{C}$ & 6 \\
\hline \multirow[t]{2}{*}{ RM234 } & F-5 "ACAGTATCCAAGGCCCTGG 3" & $63.8^{\circ} \mathrm{C}$ & $55^{\circ} \mathrm{C}$ & 7 \\
\hline & R-5 "CACGTGAGACAAAGACGGAG 3" & $63.5^{\circ} \mathrm{C}$ & $55^{\circ} \mathrm{C}$ & 7 \\
\hline \multirow[t]{2}{*}{ RM228 } & F-5 “CTGGCCATTAGTCCTTGG 3” & $60.6^{\circ} \mathrm{C}$ & $55^{\circ} \mathrm{C}$ & 10 \\
\hline & R-5 “GCTTGCGGCTCTGCTTAC 3" & $63.8^{\circ} \mathrm{C}$ & $55^{\circ} \mathrm{C}$ & 10 \\
\hline \multirow[t]{2}{*}{ RM21 } & F-5 “ACAGTATTCCGTAGGCACGG 3” & $63.7^{\circ} \mathrm{C}$ & $55^{\circ} \mathrm{C}$ & 11 \\
\hline & R-5 “ GCTCCATGAGGGTGGTAGAG 3” & $63.6^{\circ} \mathrm{C}$ & $55^{\circ} \mathrm{C}$ & 11 \\
\hline \multirow[t]{2}{*}{ RM20 } & F-5 “ АTCTTGTCCCTGCAGGTCAT 3” & $63.5^{\circ} \mathrm{C}$ & $55^{\circ} \mathrm{C}$ & 12 \\
\hline & R-5 "GAAACAGAGGCACATTTCATTG 3" & $63.3^{\circ} \mathrm{C}$ & $55^{\circ} \mathrm{C}$ & 12 \\
\hline \multirow[t]{2}{*}{ RM44 } & F-5 “ACGGGCAATCCGAACAACC 3" & $63.3^{\circ} \mathrm{C}$ & $55^{\circ} \mathrm{C}$ & 8 \\
\hline & R-5“ TCGGGAAAACCTACCCTACC 3” & $63.3^{\circ} \mathrm{C}$ & $55^{\circ} \mathrm{C}$ & 8 \\
\hline \multirow[t]{2}{*}{ RM 444} & F-5 “GCTCCACCTGCTTAAGCATC 3” & $63.8^{\circ} \mathrm{C}$ & $55^{\circ} \mathrm{C}$ & 3 \\
\hline & R-5“"TGAAGACCATGTTCTGCAGG 3” & $62.9^{\circ} \mathrm{C}$ & $55^{\circ} \mathrm{C}$ & 3 \\
\hline
\end{tabular}

${ }^{*} \mathrm{Tm}$ and $\mathrm{Ta}^{*}$ represent the melting temperature and annealing temperature of the primers, respectively.

2', 'Kaminibhoga-2'. The second group contained 'Ganjeikalli' and the third group contained 'Dubraj', 'Sujata,' 'Chatianaki', 'Basumati Bhog', 'Basmatidhan', 'Basnaparijat', and remaining varieties were placed in IV group in the co-ordinate axis (Figure 4). The phenotypic characteristics had positive correlation with polymorphic information content. The PIC ranged from 0.07 to 0.74 with an average of 0.582 (Table 4). The molecular data were generally correlated with variation at the morphological level in the crop plants and therefore provide good guidance on the distribution of useful variation as well as on the existence of co-adapted gene complexes (Hawtin et al., 1997). Despite the fact that the SSR markers used in our study are considered neutral, the genomic fingerprinting profile of each germplasm does not vary from one environment to another, reflecting the capacity of an individual plant or population to adapt (Virk et al., 1996). This direct association between the fingerprint of an accession and the phenotypic response to a target environment is caused by linkage disequilibrium, which in rice is mainly due to autogamous reproduction (Ford-Lloyd et al., 1997). Neutral markers can be used to establish the evolutionary past of varietal groups and to account for pre-selection of the germplasm to be used in breeding programs (Glaszmann et al., 1996; Brondani et al., 2006). One of the implications of SSR analysis for landrace conservation is that the genotyping of landraces can detect differences that cannot be detected by traditional methods of morphological characterization used routinely in gene banks. The knowledge of within genotypic variability is important for conservation purposes, because it is possible to determine the most genetically variable accessions which would demand an additional effort of sampling a higher quantity of seeds in order to preserve this genetic variability and prevent genetic drift during routine periodic germplasm multiplication. The analysis of individual plants of an accession is also relevant for breeding purposes, since homozygous plants can be selected and used as genitors in crosses with elite rice genotypes. In addition, marker-based identification and differentiation of aromatic rice could be helpful to preserve the integrity of the high quality rice varieties to benefit farmers, breeders and consumers communities.

\section{ACKNOWLEDGEMENT}

The authors are thankful to the Department of 


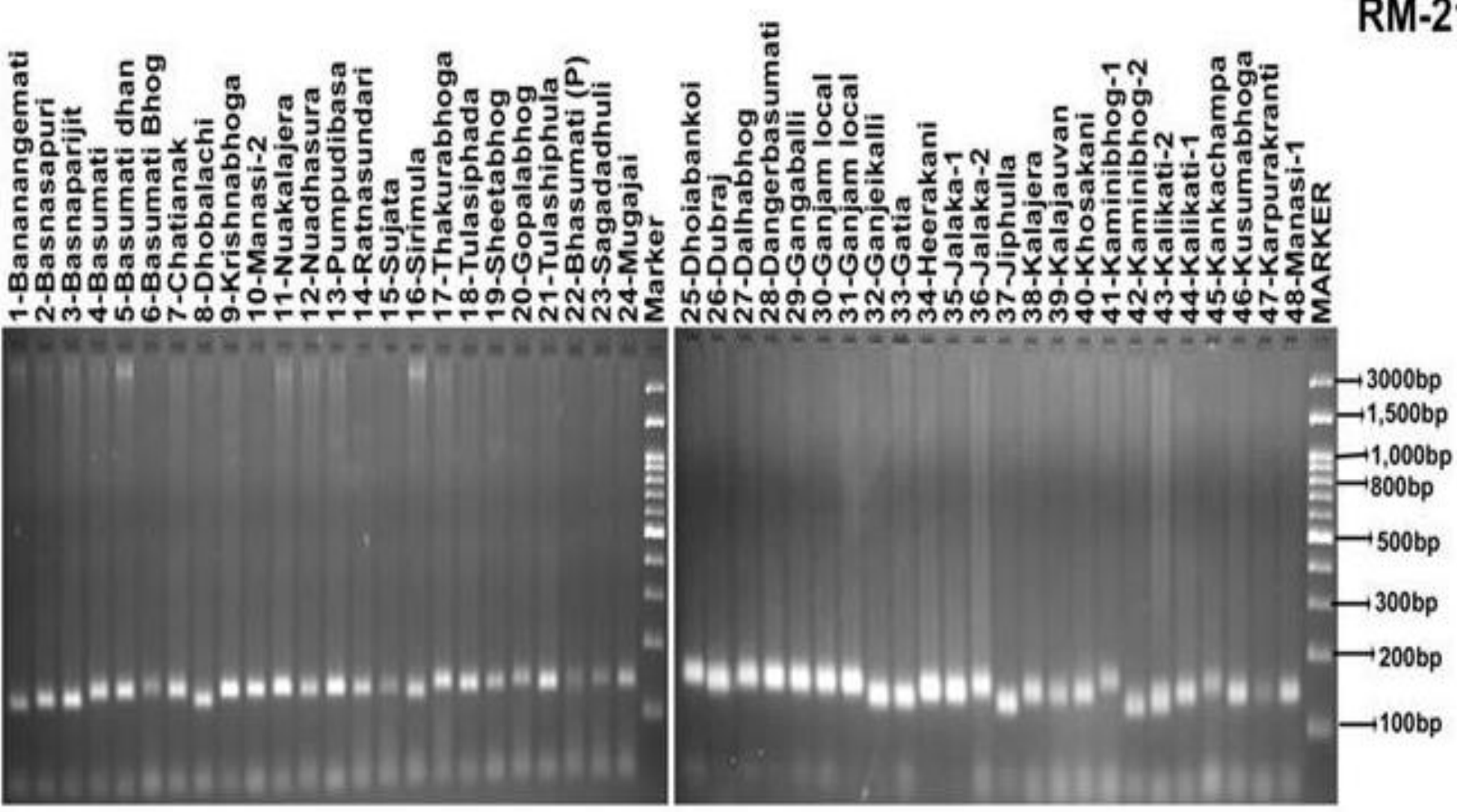

RM-20

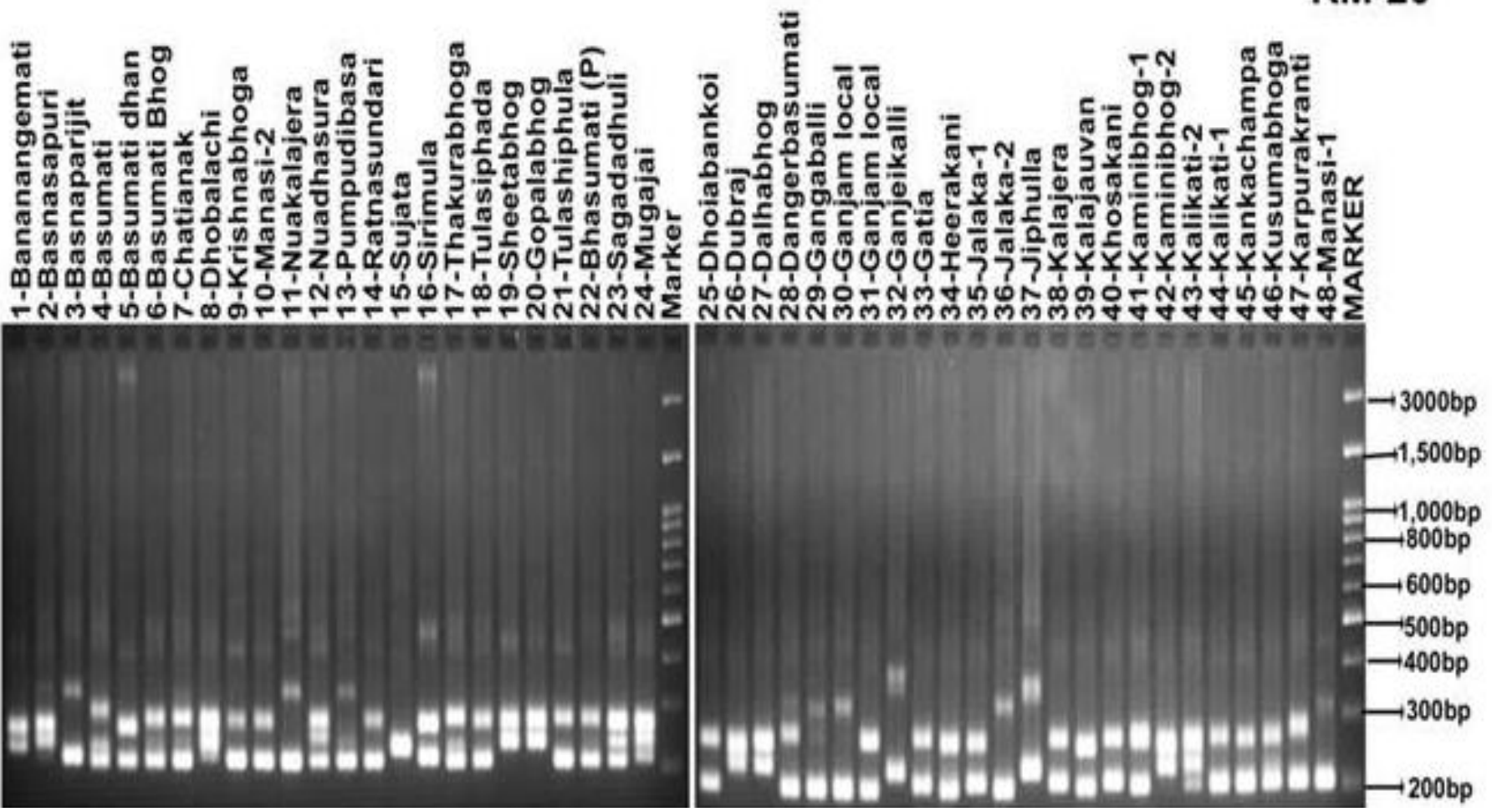

Figure 2. DNA amplification profile of 48 aromatic rice genotypes using SSR markers. 


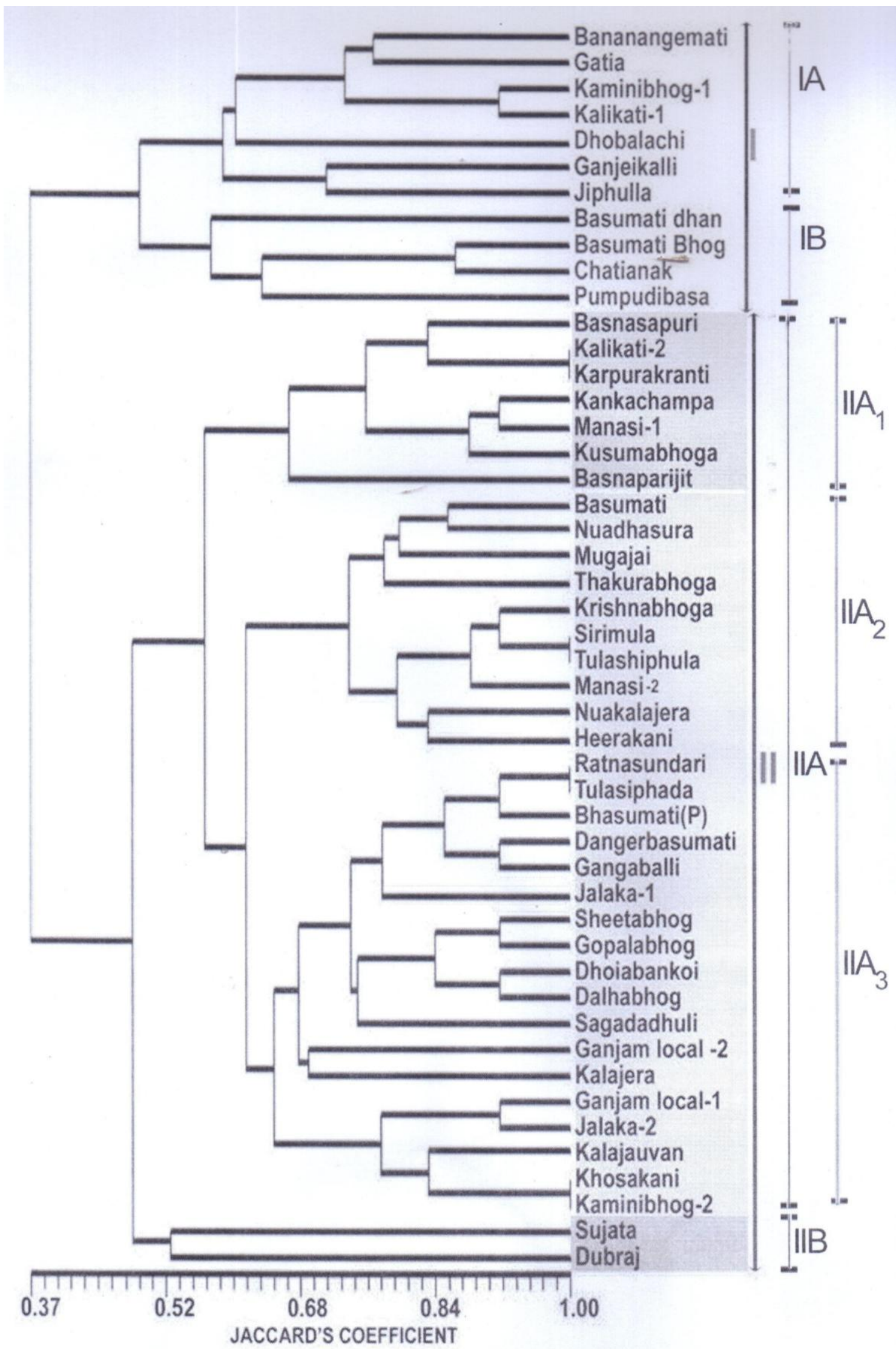

Figure 3. Cluster analysis of 48 aromatic rice genotypes on the basis of similarity index. 


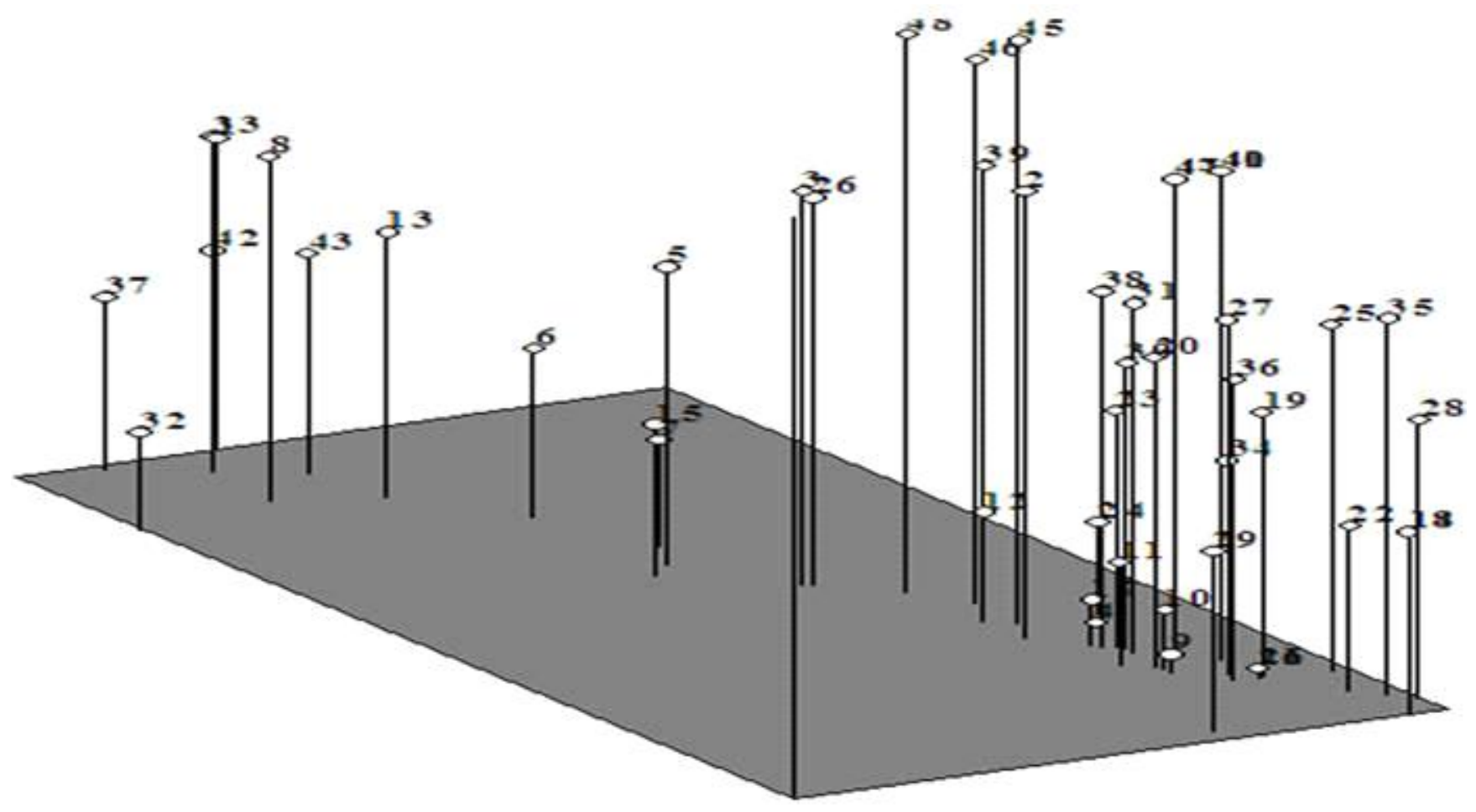

Figure 4. 3D PCA analysis of 48 aromatic rice genotypes on the basis of similarity index.

Table 4. DNA profile and polymorphism generated in 48 Aromatic rice genotypes using 12 SSR primers.

\begin{tabular}{cccccccc}
\hline Chromosome & $\begin{array}{c}\text { Position } \\
\text { (cM) }\end{array}$ & $\begin{array}{c}\text { Primer } \\
\text { code }\end{array}$ & $\begin{array}{c}\text { Number } \\
\text { of alleles }\end{array}$ & $\begin{array}{c}\text { Number of } \\
\text { polymorphic alleles }\end{array}$ & $\begin{array}{c}\text { Percentage } \\
\text { polymorphism (bp) }\end{array}$ & $\begin{array}{c}\text { Size } \\
\text { Range(bp) }\end{array}$ & $\begin{array}{c}\text { Average } \\
\text { PIC value }\end{array}$ \\
\hline 1 & 92.4 & RM 9 & 2 & 2 & 100 & $100-150$ & 0.74 \\
2 & 4.8 & RM154 & 4 & 2 & 50 & $100-220$ & 0.39 \\
3 & 67.8 & RM218 & 2 & 2 & 100 & $100-120$ & 0.74 \\
4 & 106.2 & RM241 & 2 & 2 & 100 & $150-180$ & 0.69 \\
5 & 55.6 & RM249 & 2 & 2 & 100 & $120-150$ & 0.53 \\
6 & 125.4 & RM30 & 2 & 2 & 100 & $100-110$ & 0.74 \\
7 & 88.2 & RM234 & 2 & 2 & 100 & $140-180$ & 0.59 \\
10 & 130.3 & RM228 & 2 & 2 & 100 & $100-150$ & 0.49 \\
11 & 85.7 & RM21 & 2 & 2 & 100 & $110-190$ & 0.65 \\
12 & 3.2 & RM20 & 5 & 5 & 100 & $100-210$ & 0.71 \\
8 & 60.9 & RM44 & 1 & 0 & 0 & 130 & 0 \\
9 & 3.3 & RM444 & 2 & 2 & 100 & $130-180$ & 0.71 \\
& & Total & 28 & 25 & - & - & 6.99 \\
& & Mean & 2.33 & 2.08 & - & - & 0.582 \\
\hline
\end{tabular}

Biotechnology, Government of India for providing the student research fund under PG-HRD program.

\section{REFERENCES}

Aggarwal RK, Shenoy VV, Ramadevi J, Rajkumar R, Singh L (2002).
Molecular characterization of some Indian Basmati and other elite rice genotypes using fluorescent -AFLP. Theor. Appl. Genet. 105:680-690

Brondani C, Borba TCO, Rangel PHN, Brondani RPV (2006). Determination of genetic variability of traditional varieties of Brazilian rice using microsatellite markers. Genetics and Molecular Biology, 29:676-684.

Choudhury PR, Kohli S, Srinivasan K, Mohapatra T, Sharma RP (2001). 
Identification and classification of aromatic rices based on DNA fingerprinting. Euphytica 118(3):243-251.

Doyle JJ, Doyle JL (1990). Isolation of plant DNA from fresh tissue. Focus 12:13-15.

Ford-Lloyd BV, Jackson MT, Newbury HJ (1997). Molecular markers and the management of genetic resources in seed genebanks: $A$ case study of rice. In: Callow JA, Ford-Lloyd BV, Newbury HJ (eds) Biotechnology and Plant Genetic Resources - Conservation and Use. CAB, Wallingford. pp. 103-118.

Gao LZ, Zhang CH, Chang LP, Jia JZ, Qiu ZE, Dong YS (2005). Microsatellite diversity within Oryza sativa with emphasis on indicajaponica divergence. Genet Res. 85:1-14.

Garris AJ, Tai TH, Coburn JR, Kresovich S, McCouch S (2005). Genetic structure and diversity in Oryza sativa L. Genetics, 169:1631-1638.

Glaszmann JC, Mew T, Hibino H, Kim CK, Dios-Mew TIV, Cruz CMV, Notteghem JL, Bonman JM (1996). Molecular variation as a diverse source of disease resistance in cultivated rice. Proceedings of the Third International Rice Genetics symposium, Manila, Philippines. pp. 460-465.

Hawtin G, Iwanaga M, Hodgkin T (1997). Genetic resources in breeding for adaptation. In: Tigerstedt PMA (Ed) Adaptation in Plant Breeding. Kluwler, New York. pp. 277-288.

Jain S, Jain RK, McCouch SR (2004). Genetic analysis of Indian aromatic and quality rice (Oryza sativa L.) germplasm using panels of fluorescently-labeled microsatellite markers. Theo. Appl. Genet. 109(5):965-977.

Jayamani P, Negrao S, Martins M, Macas B, Oliveria MM (2007). Genetic relatedness of Portuguese rice accessions from diverse origins as assessed by microsatellite markers. Crop Sci. 47(2):879884.

McCouch SR, Chen X, Panaud O, Temnykh S, Xu Y, Cho YG, Huang $\mathrm{N}$, Ishii T, Blair M (1997). Microsatellite mapping and applications of SSLP's in rice genetics and breeding. Plant Mol. Biol. 35:89-99.

Nagaraju J, Kathirvel M, Kumar RR, Siddiq EA, Hasnain SE (2002). Genetic analysis of traditional and evolved Basmati and non-Basmati rice varieties by using fluorescence-based ISSR-PCR and SSR markers. Proc. Natl. Acad. Sci. USA. 99:5836-5841

Pervaiz ZH, Rabbani MA, Pearce,SR, Malik SA (2009). Determination of genetic variability of Asian rice (Oryza sativa L.) varieties using microsatellite markers. Afr. Jour. Biotech. 8:5641-5651,

Powel W, Morgante M, Andre C, Hanafey M, Vogel J, Tingey S, Rafalski A (1996). Comparison of RFLP, RAPD, AFLP and SSR markers for germplasm analysis. Mol. Breed. 2(3):225-238.

Ram SG, Thiruvengadam V, Vinod KK (2007). Genetic diversity among cultivars, landraces and wild relatives of rice as revealed by microsatellite markers. Jour. Appl Genetics 48:337-345

Ray S, Agarwa P, Arora R, Kapoor S, Tyagi AK (2007). Expression profile of calcium-dependent protein kinase gene family during reproductive development and abiotic stress conditions in rice (Oryza sativa L. ssp. Indica). Mol. Gen. Genomics 278:493-505.
Ren F, Lu BR, Li S, Huang J, Zhu Y (2003). A comparative study of genetic relationships among the AA-genome Oryza species using RAPD and SSR markers. Theo. Appl. Genet. 108(1):113-120.

Rohlf FJ (2002). NTSYS pc Numerical taxonomy and multivariate system Ver. 2.1 Exeter Publ Ltd, Setauket, New York.

Sajib AM, Hossain MM, Mosnaz ATMZ, Hossain H, Islam MM, Ali MS, Prodhan SH (2012). SSR marker-based molecular characterization and genetic diversity analysis of aromatic landreces of rice (Oryza sativa L.). J. BioSci. Biotech. 1(2):107-116.

Saini N, Jain N, Jain S, Jain RK (2004). Assessment of genetic diversity within and among Basmati and non-Basmati rice varieties using AFLP, ISSR and SSR markers. Euphytica. 140(3):133-146.

Sambrook J, Fritsch EF, Maniatis T (1989). In: Molecular Cloning: A Laboratory Manual. Cold Spring Harbor Laboratory Press, Vol. 1, 2, 3, NY, USA.

Shishido R, Kikuchi M, Nomura K, Ikehashi H (2006). Evaluation of genetic diversity of wild rice (Oryza rufipogon Griff.) in Myanmar using simple sequence repeats (SSRs). Genetic Res. Crop Evol. 53(1):179-186.

Singh RK, Sharma RK, Singh AK, Singh VP, Singh NK, Tiwari SP, Mohapatara $T$ (2004). Suitability of mapped sequence tagged microatellite site markers for establishing distinctness, uniformity and stability in aromatic rice. Euphytica, 135:135-143.

Sneath PHA, Sokal RR (1973). Numerical taxonomy. The principles and practice of numerical classification W.H Freeman San Francisco CA

Temnykh S, Park WD, Ayres N, Cartinhour S, Hauck N, Lipovich L, Cho YG, Ishii T, McCouch SR (2000). Mapping and genome organization of microsatellite sequences in rice (Oryza sativa L.). Theor. Appl. Genet. 100:697-712.

Veteläinen M, Nissilä E, Tigerstedt PMA, Bothmer R (1997). Utilization of exotic germplasm in Nordic barley breeding and it consequences for adaptation. In: Tigerstedt PMA (ed) Adaptation in Plant Breeding. Kluwler, New York. pp. 289- 295.

Virk PS, Ford-Lloyd BV, Jackson MT, Pooni HS, Clemeno TP, Newbury HJ (1996). Predicting quantitative variation within rice germplasm using molecular markers. Heredity 76:296-304.

Thomson MJ, Septiningsih EM, Endang M, Suwardio F, Santoso TJ, Silitonga TS, McCouch SR (2007). Genetic diversity analysis of traditional and improved Indonesian rice (Oryza sativa L.) germplasm using microsatellite markers. Theo. Appl. Genet. 114(3):559-568.

Yu SB, Xu WJ, Vijayakumar CHM, Ali J, Fu BY, Xu JL, Jiang YZ, Marghirang R, Domingo J, Aqino C, Virmani SS, Li ZK (2003). Molecular diversity and multilocus organization of the parental lines used in the International Rice Molecular Breeding Program. Theo. Appl. Genetics, 108(1):131-140.

Zeng L, Kwon T, Liu X, Wilson C, Grieve CM, Gregorio GB (2004). Genetic diversity analyzed by microsatellite markers among rice (Oryza sativa L.) genotypes with different adaptations to saline soils. Plant Sci. 166(5):1275-1285. 